\title{
Na parada do lazer: delineando as ações de lazer em ONGs LGBT de Belo Horizonte
}

CDD. 20.ed. 790.1

http://dx.doi.org/10.1590/1807-55092014000400579

\author{
Marie Luce TAVARES* \\ Hélder Ferreira ISAYAMA**
}

*Instituto Federal de
Educação, Ciência e
Tecnologia de Minas
Gerais.
**Escola de Educação
Física, Fisioterapia e
Terapia Ocupacional,
Universidade Federal
de Minas Gerais.

0 presente estudo objetivou diagnosticar e analisar as ações de lazer das Organizações Não Governamentais ligadas ao Movimento LGBT de Belo Horizonte/MG. Assim, apresentamos como proposta metodológica a pesquisa documental combinada com a de campo, aplicando a imersão no campo e as entrevistas semiestruturadas como instrumentos de coleta de dados. Foram analisadas duas instituições, sendo entrevistados seis profissionais que atuam no âmbito do lazer. Os objetivos dessas ações variam, cabendo a elas desde 0 trabalho da autoestima até o empoderamento desse público visando a seu protagonismo social. Há uma multiplicidade de ações que envolvem os diversos conteúdos do lazer, das artes às atividades físicas. Assim, este trabalho traz algumas provocações que convidam a pensar o campo de atuação profissional em lazer em ONGs LGBT: o planejamento participativo das ações; a utilização e apropriação dos espaços públicos para o lazer; os investimentos no setor; e a conscientização do lazer como direito.

PalAVRAS-ChaVE: Lazer; Atuação profissional; Organização não governamental; Movimento LGBT.

\section{Introdução}

$\mathrm{Na}$ atualidade, assistimos a uma crescente demanda direcionada ao Estado, que, ao náo dar conta de atendê-la, transfere sua responsabilidade para o terceiro setor, subsidiando-o. A partir desse modelo de organizaçáo decorrem arranjos diversificados que, na maioria dos casos, acabam também náo resolvendo o problema da pobreza, da miséria e da exclusão. Nessa nova forma de gestấo pública, as políticas sociais tendem a abarcar segmentos populacionais em situação de maior risco e vulnerabilidade social. A pobreza e a desigualdade configuram-se como questóes de solidariedade social, formando a base de um sistema misto de proteção que concilia iniciativas do Estado e do terceiro setor. Promovem-se, assim, a refilantropização da questão social e a despolitização da política social ${ }^{1}$.

Nesse contexto, buscamos compreender o lugar do lazer, direito social, nas iniciativas do terceiro setor. Para LOPEs ${ }^{2}$

Nesse caminho de ampliação e reconfiguração dos direitos, o lazer é estabelecido pela Constituição de 1988 como um direito social, merecendo e se tornando obrigatoriamente um assunto a ser tratado pelo Estado por meio das políticas públicas. Esse marco lógico inaugura uma nova maneira de conceber o lazer que, mesmo estabelecendo uma relação direta com o trabalho, passa a ser reconhecido como uma riqueza cultural que deve ser garantida a todos os cidadãos como premissa de qualidade de vida (p.54-5).

Contudo, a partir do contraditório cenário delineado pela crise do Welfare State e pela ascensão neoliberal, as alternativas traçadas não garantiram o direito ao lazer e acentuaram a privatizaçáo dos direitos sociais no Brasil. É inegável o avanço do neoliberalismo a partir da década de 90 , assim como também o é a crise de legitimidade por que passou o Estado Social, estimulando seu questionamento.

Nesse sentido, perguntamos: como tem sido travada a luta pela garantia desse direito? As consideraçôes de $\mathrm{MeNICUCCI}^{3}$ a esse respeito nos apontam a necessidade de

[...] desmontar esperanças em um ativismo estatal isolado da construção social de um ideário relativo ao lazer, processo que envolve uma definição de lazer e de políticas de lazer, dos princípios e diretrizes a orientar essa política, 
dos conteúdos principais e das formas de sua implementação (p.141).

Dessa forma, torna-se necessária a ação de um conjunto de atores sociais que, comungando de uma mesma concepção, buscam incluir o tema na agenda pública. No que se refere à superação das diferenças e das desigualdades, podemos situar o surgimento de movimentos sociais que vêm lutando para que a sociedade possa considerar de maneira adequada as diversas formas e escolhas da vida em sociedade, sem preconceitos, estereótipos e discriminações. Mesmo correndo o risco de fragmentação da luta pela construção de uma nova ordem social, não podemos negar a importância e a contribuição desses movimentos.

\section{Método}

No intuito de atingir os objetivos propostos estabelecemos uma metodologia de trabalho compreendendo a pesquisa documental combinada com a pesquisa de campo. Utilizamos os documentos (estatutos das instituiçóes, atas de reuniôes, folders e informativos dos eventos), a imersão no campo e as entrevistas semi-estruturadas como instrumentos de coleta de dados. Os documentos nos auxiliaram a estruturar nossa imersáo no campo, nos norteando para as atividades desenvolvidas no âmbito do lazer. Ponderando que as atividades desenvolvidas pelas instituiçóes definidas de cunho cultural poderiam ser incluídas como atividades de lazer, não hesitamos em incluir as pessoas envolvidas na organização e execução dessas atividades como sujeitos desta pesquisa.

Estabelecemos os seguintes critérios para a definição das organizaçóes: ser uma organização não governamental que trata das questóes voltadas ao Movimento LGBT e a constatação de açóes de lazer em seu planejamento. Assim, encontramos duas instituiçóes que atenderam aos critérios: a Associação Lésbica de Minas (ALEM) e o Centro de Luta pela Livre Orientação Sexual (CELLOS).

As duas organizaçóes foram contatadas para a apresentação do projeto aos dirigentes das instituições. Prestamos informaçóes sobre os objetivos e sobre a metodologia a ser empregada, verificando a disponibilidade de participarem do estudo. Cabe ressaltar que a carta de anuência foi prontamente assinada e os profissionais autorizados a participarem, caso optassem por contribuir. No ato da assinatura da carta de anuência, ambas as instituiçôes também concordaram
É diante desses pressupostos que buscamos refletir acerca das açóes no âmbito do lazer no terceiro setor, considerando os seguintes aspectos: a nova faceta da gestão pública no que tange aos direitos sociais, a partir da transferência das responsabilidades do Estado para esse setor; e a sua gestão, a partir das ações das organizaçôes do Movimento de Lésbicas, Gays, Bissexuais, Travestis e Transexuais (LGBT), no enfrentamento às desigualdades. Assim, o objetivo desse trabalho é diagnosticar e analisar as ações de lazer das Organizaçóes Não Governamentais (ONGs) ligadas ao Movimento LGBT de Belo Horizonte, buscando identificar e analisar os objetivos, público-alvo, planejamento e avaliação, espaços e equipamentos, bem como os limites e dificuldades para o desenvolvimento dessas ações.

com sua identificação no texto da pesquisa. A documentação foi encaminhada ao Comitê de Ética da Universidade Federal de Minas Gerais (UFMG), que analisou o projeto de pesquisa e autorizou a realização do estudo. A partir disso, realizamos o contato com as instituições para darmos início à pesquisa.

Acompanhando o cotidiano das instituiçóes, tivemos ciência da ausência de profissionais específicos para atuar nas diferentes frentes de ação da instituiçáo, ao mesmo tempo em que havia um diversificado grupo de pessoas envolvidas nas atividades. Com o intuito de compreender as diferentes etapas de organização das atividades e espaços de atuação, decidimos abordar os profissionais envolvidos com a área do lazer, delimitando o sujeito alvo da pesquisa de acordo com sua aproximação às fases de organização das atividades de lazer: captação de recursos, planejamento, execução e avaliação. A escolha de sujeitos para as entrevistas que se enquadrassem nos critérios estabelecidos se deu a partir dos dados levantados pela imersão de campo e por sugestão dos dirigentes. Aos entrevistados solicitamos ainda que autorizassem o uso das informaçóes e garantimos o anonimato no tratamento dos dados. Para isso, ao invés dos nomes, adotamos números ao nos referirmos aos sujeitos da pesquisa, com o objetivo de resguardá-los de qualquer tipo de exposição.

Realizamos seis entrevistas semiestruturadas, norteadas por um roteiro composto por 16 perguntas, que abordavam desde a relação do entrevistado com a instituição, o processo de seleção e contratação dos profissionais bem como sua formação, às atividades de lazer. Para a elaboração do roteiro de entrevistas 
consideramos os documentos aos quais tivemos acesso e a imersão no campo. As entrevistas, com duração média de 40 minutos, foram gravadas e transcritas. Deste recorte metodológico, buscamos elementos que auxiliassem na construção do diagnóstico e que conferissem sentido e significado às açôes no âmbito do lazer. Por fim, para o tratamento dos dados utilizamos como instrumento a análise de conteúdo, que de acordo com BARDIN ${ }^{4}$ é " [...] um conjunto de técnicas de análise das comunicaçóes que utiliza procedimentos sistemáticos e objetivos de descriçâao do conteúdo das mensagens" (p.38). Tais procedimentos são criteriosos, com muitos aspectos observáveis, mas que colaboram bastante no desvendar dos conteúdos de seus documentos.

BARDIN $^{4}$ assinala três polos cronológicos que marcam fases distintas da análise. A primeira é a pré-análise, fase da organização propriamente dita. A exploraçáo do material é a fase seguinte, caracterizada pela administraçáo sistemática das decisōes tomadas na fase anterior. Por fim, a fase de

\section{Resultados e discussão}

O palco de atuação: Associação Lésbica de Minas (ALEM) e o Centro de Luta pela Livre Orientação Sexual (CELLOS)

A ALEM nasce dentro de um contexto institucionalizado, estabelecendo relaçóes com partidos políticos de esquerda e movimentos sociais diversos. Nesse sentido, seu campo de atuação - que parte de um objetivo de representação - é ampliado também para atividades de atendimento da população LGBT, mas de forma a manter um posicionamento antagônico à política neoliberal e de direita.

A ALEM parte de uma tentativa de representar politicamente o segmento das lésbicas, e sua origem se dá a partir de um grupo misto, o Grupo de Lésbicas, Gays e Simpatizantes de Minas Gerais, organizado pela atual dirigente em 1997 (e registrado em 1999), que tinha como principal bandeira combater o preconceito e a discriminação dirigidos à comunidade LGBT. A ideia de criação do grupo se deu com o envolvimento desta militante ${ }^{\mathrm{b}}$ com o movimento nacional de lésbicas.

Assim, a fundação da ALEM é motivada pela necessidade de se criar um espaço para que as mulheres lésbicas se organizassem para o enfrentamento da discriminação e para lutar por direitos, promovendo tratamento dos resultados obtidos e interpretação. Nesta fase, os resultados brutos são tratados de maneira a serem significativos e válidos, são elaborados quadros de resultados, diagramas, figuras, modelos, os quais condensam e póem em relevo informações fornecidas pela análise.

Diante do exposto e a partir do arcabouço teórico construído, buscamos realizar uma leitura desses eixos, e para tanto os agrupamos a partir das seguintes temáticas: ações, objetivos, público atendido, planejamento, espaços e equipamentos relacionados, bem como os limites, dificuldades e potencialidades do serviço no terceiro setor.

Cabe, portanto, ressaltar que antes de iniciar o tratamento e a exposição dos dados interpretados apresentaremos as duas organizaçóes não governamentais a partir do nosso olhar investigativo - consubstanciado nos documentos aos quais tivemos acesso -, que, apesar de metodologicamente delimitado, não quisemos nos fazer, em momento algum, neutros e isentos de opiniôes. seu empoderamento. A ALEM foi composta por lésbicas que saíram de movimentos sindicais, estudantis e políticos, com o objetivo de ampliar a discussão acerca da homossexualidade, até então inexistente nesses espaços, com o objetivo de assumir a lesbianidade feminista como postura política para desconstruir o patriarcado como sistema de opressão com suas instituiçôes e ideologias. Conforme seu estatuto, a instituição delineou como missão os seguintes objetivos: ser referência na luta contra o preconceito e a discriminação dirigidos às lésbicas e bissexuais femininas e por direitos reprodutivos e sexuais das mulheres; buscar combater toda forma de violência contra as mulheres; promover a Visibilidade Lésbica; lutar contra as desigualdades e injustiças sociais das quais as mulheres são as principais vítimas ${ }^{5}$ (p.1). A trajetória política da maioria das militantes que integram a entidade conserva fortes traços das formas tradicionais de militância sindical e partidária de esquerda, o que acabou dando à entidade essas características.

Estruturalmente, em respeito a seu estatuto, a ONG tem um corpo de responsáveis jurídicas; entretanto, no fazer cotidiano da instituição, há outro grupo de mulheres, que se responsabilizam pelas atividades, parcerias, enfim, pelo dia a dia da ALEM. Quanto a sua base organizacional, a instituição se pauta nas decisões 
tomadas no coletivo, em assembleia. As decisóes mais importantes são adotadas em reunião com esse grupo de mulheres que dirigem o cotidiano da instituição, mas também existem reunióes abertas para todas as afiliadas e mulheres que quiserem comparecer.

Para a manutenção da entidade, a ALEM conseguiu internacionalizar contatos e financiamentos para suas atividades. Hoje a ONG conta com o financiamento do Global Found For Woman, que financia o funcionamento cotidiano da instituiçáo e ajudou em parte da compra da atual sede; da MAMA CASH, que financiou compra de equipamentos, móveis, bem como parte da compra da sede; da ASTRAEA (Lesbian Foundation For Justice), que também financiou parte da compra da sede e vem financiando várias atividades, como seu funcionamento cotidiano. Além disso, a instituição busca realizar parcerias para execução de projetos e atividades.

A ALEM também estabelece parcerias com o poder público para receber recursos para projetos de prevenção às Doenças Sexualmente Transmissíveis/AIDS (DST/AIDS), como a Coordenação Estadual DST/AIDS e a Coordenação Municipal DST/AIDS. Para o estabelecimento de parcerias, a instituição definiu alguns critérios, e o primordial é a afinidade com suas reivindicações.

O CELLOS também tem suas origens ligadas a partidos de esquerda e outros movimentos sociais. Para $\mathrm{MACHADO}^{6}$, essa ligação, assim como na ALEM, influenciou muito o estilo de militância do grupo e suas concepçóes políticas. Talvez seja por isso que as duas instituições desenvolveram uma relação muito próxima, tendo o CELLOS utilizado a sede da ALEM em seus primeiros meses de existência e a sede do Sindicato dos Empregados de Estabelecimentos de Serviços de Saúde (SINDESSE), sindicato dirigido por uma militante da ALEM, para algumas reunióes.

O CELLOS é uma organização não governamental que luta pelos direitos humanos de lésbicas, gays, bissexuais, travestis e transexuais, e pela efetivação da cidadania desse grupo social, e começa a ser pensado no ano de 2001. Segundo Fernandes ${ }^{7}$, um grupo de jovens homossexuais provindos do movimento estudantil, que militavam em partidos políticos da esquerda brasileira como o Partido dos Trabalhadores (PT), o Partido Comunista do Brasil (PC do B) e o Partido Socialista dos Trabalhadores Unificado (PSTU), uniramse com dissidentes de grupos homossexuais da capital mineira para formarem uma entidade homossexual.

Os fundadores do grupo apresentavam origens e formaçôes heterogêneas, mas compartilhavam da insatisfação com o cenário da militância da cidade, impermeável a uma discussão política mais aprofundada. Para MACHADO ${ }^{6}$ o objetivo central desse grupo era não se limitar à convivência ou à realizaçáo de ações de prevenção, mas refletir sobre essas ações, dando um caráter politizado e discutindo as questóes sociais como um todo, e não apenas a sexualidade.

Em março de 2003, o grupo realizou o lançamento da carta aberta da organização. A carta remetia à necessidade de novas respostas à homofobia e à forma como se organizavam os homossexuais, reivindicando uma entidade vinculada às lutas sociais e aos direitos humanos, que fosse capaz de dar voz aos homossexuais "mais oprimidos" de camadas populares. Com essa diretriz, o CELLOS nasce como um núcleo revolucionário de homossexuais que buscavam "conciliar" a luta geral com as demandas específicas de um público submetido à marginalização social devido às relaçôes afetivo-sexuais ${ }^{7}$.

Legalizado em 2004 como uma organização não governamental, o grupo estabelece em seu estatuto, no Art. $2^{\circ}$, os objetivos:

(i) defender os homossexuais em situação de violência; (ii) conscientizá-los de seus direitos; (iii) lutar contra o preconceito, a discriminação e a violência, formar e educar os homossexuais para que eles vivam com dignidade a [sic] suas visibilidades; (iv) promover encontros, fóruns, debates e outras formas de eventos para discussão de seus objetivos ${ }^{8}$ (p.1).

Fernandes 9 afirma que os militantes partidários preferiram a institucionalização de suas açôes em um grupo homossexual por avaliarem que, nos partidos da esquerda brasileira, a discussão sobre os temas como sexualidade, homofobia, AIDS, respectivos aos homossexuais, não era priorizada. Em contrapartida, para os dissidentes de outros grupos homossexuais, as entidades se limitavam à execução de projetos e açóes assistenciais, e não buscavam questionar e transformar o sistema capitalista no qual estamos imersos. Diante disso, para o autor, a emergência do grupo surge como resistência ao formato das outras entidades que atuavam no movimento homossexual na capital mineira.

Assim como a ALEM, o CELLOS defendia a associaçáo das questóes da sexualidade com outras demandas sociais. Dessa forma, a sexualidade é tratada pelo grupo como parte da trama que envolve outros elementos identitários, como raça, classe social, sexo e gênero, ocupação, faixa etária. Os integrantes da instituição participam de uma rede de movimentos sociais que ultrapassa as fronteiras do Movimento LGBT: Movimento Negro, Movimento Feminista, Movimento Estudantil, dentre outros. 
Inicialmente, como característica de composição, a entidade tinha o seu quadro formado exclusivamente por gays, afirmando nessa metodologia de ação as especificidades do segmento; diferenciandoos de identidades lésbicas, travestis e transexuais. Assim como a ALEM, o CELLOS defendia a importância dos grupos tratarem das demandas específicas de apenas um segmento. Mesmo desenvolvendo açóes em parceria com outras instituições e representantes de outras minorias sociais, os militantes do CELLOS foram críticos aos grupos mistos e se colocaram como uma entidade direcionada aos homens homossexuais. Juntamente com a ALEM e a Associação de Travestis e Transexuais (ASSTRAV), o CELLOS auxiliou na coordenação participativa do Centro de Referência da Diversidade Sexual, órgão da Prefeitura de Belo Horizonte, vinculado à Coordenadoria de Direitos Humanos e ligado à Secretaria Municipal de Direitos de Cidadania.

Contrariando esse posicionamento, em 2007 a instituiçâo formou um núcleo de lésbicas dentro do CELLOS. Essas mulheres buscaram a instituição por não se identificarem com a política da ALEM. A diretoria do CELLOS vem buscando formas de incluir essas mulheres no grupo, sem inferiorizá-las. A partir do ano de 2010, a instituição também incluiu um núcleo de travestis, tendo atualmente como vice-presidente uma representante desse segmento. A instituição passou por um processo de reestruturaçáo, que segundo um dos entrevistados passou a se estabelecer da seguinte forma:

[...] tem a direção, são os responsáveis jurídicos pela entidade, alguns foram convidados, mas basicamente hoje a direção toda está dentro do nosso estatuto, então cada um hoje composto pela direção é responsável pela entidade. [...] nós temos duas mulheres na direção também, e a vice-presidente do CELLOS é travesti. Como o nome da entidade: Centro de Luta pela Livre Orientação Sexual, o grupo nasceu praticamente masculino, de gays, só que o intuito nosso era ter a diversidade aqui dentro, tanto de travestis, quanto de lésbicas, aí hoje a gente tem uma travesti, temos duas mulheres que fazem parte do grupo também, mas ainda é organizada diretamente por gays, que tomam a frente. Além da direção, a gente tem a base, [...] que são os militantes; eles não são responsáveis diretamente, não respondem juridicamente pela entidade, em questão de assinar documentação, mas fazem parte da entidade (entrevistado 5 - CELLOS).

Assim como a ALEM, a estruturação do CELLOS foi fortemente influenciada pela militância característica de partidos de esquerda; isso contribuiu para o desenvolvimento de um estilo próprio de atuação e concepçáo política, que, por sua vez, traz novos modos de pensar e conceber as relaçóes políticas dentro do Movimento LGBT. Refletir acerca das temáticas LGBT inseridas em um contexto mais amplo de demandas pode ser um caminho político democrático e transformador. O CELLOS, bem como a ALEM, ao fazerem a opçáo pelo discurso de esquerda, limitaram as possibilidades articulatórias com setores da direita $\mathrm{e}$, consequentemente, com determinados aspectos da gramática política do Movimento LGBT contemporâneo, tal como podemos perceber na crescente mercadorização ${ }^{c}$ das formas de atuação política e da produção de algumas Paradas LGBT no Brasil ${ }^{6}$.

Diante disso, é importante enfatizarmos que a instituição desenvolveu ampla relação com o terceiro setor e órgáos do Estado responsáveis por políticas sociais. Nessa direção, participam de atividades como: Conferência Nacional de Direitos Humanos; Centro de Referência da Diversidade Sexual, onde realizam o atendimento às vitimas de discriminação e homofobia, e fazem encaminhamento jurídico e psicológico; Frente Parlamentar contra a homofobia em Belo Horizonte, entre tantas outras. Além disso, estabelecem parcerias com o Conselho Regional de Psicologia, o Conselho Regional de Serviço Social, Ouvidoria de Polícias, o Centro de Atendimento de Penas Alternativas, o Núcleo de Psicologia Política da UFMG e o Programa Conexão de Saberes da UFMG, e muitas dessas parcerias auxiliam na execução das atividades da instituição.

Ambas as instituiçóes estabelecem parcerias com o poder público, e neste contexto, é importante destacar a relaçáo do Estado com essas instituiçóes no que tange ao repasse de recursos. A chamada " $p u$ blicização" - definida por Bresser PereirA ${ }^{10}$ como transformação dos serviços não exclusivos de Estado em propriedade pública não estatal e sua declaração como organização social - culminou na transferência da responsabilidade do Estado para o mercado ou o chamado "terceiro setor". Para Yамамото ${ }^{11}$, são essas as respostas neoliberais às refraçôes da "questão social", que culminou na precarização dos serviços d. Isso se reflete na descentralizaçáo dos serviços, que implica transferência de responsabilidade aos níveis locais do governo e à oferta de serviços deteriorados e sem financiamento; e na focalização que introduziu um corte de natureza discriminatória para o acesso aos serviços sociais básicos pela necessidade de comprovação da "condição de pobreza". Dessa forma, percebemos aqui "resquícios" desse modelo de organização, que são as ONGs. Enquadradas no 
terceiro setor, por serem entidades sem fins lucrativos e se responsabilizarem pelas questóes sociais, trazem consigo todas essas carências estruturais e financeiras, e acabam não dando conta de se estruturarem.

O estabelecimento de redes de cooperaçáo, o sistema de parcerias para efetivaçáo e andamento das atividades, bem como para o funcionamento das instituiçôes, são características que acompanham as instituiçốes do terceiro setor, principalmente aquelas vinculadas a movimentos sociais. Muitas dessas parcerias são firmadas com o próprio Estado, conforme ressalta um dos entrevistados do CELLOS.

$\mathrm{Na}$ maioria das vezes essa relação é mais próxima com o poder público, justamente porque são questôes que deveriam estar sendo feitas pelo poder público. Então a prefeitura, na maioria das vezes, é a maior parceira, até porque a prefeitura não tem uma atividade esportiva, esportes. Se você for na Secretaria de Esportes, você vai ver que não tem uma atividade relacionada para o segmento LGBT, não tem. Essa contrapartida que o movimento social, a partir da ONG, está oferecendo é muito nessa relação entre o déficit do Estado, o déficit da prefeitura enquanto Estado, o déficit do Estado em garantir o direito das pessoas até porque a educação é um direito, a cultura é um direito, o lazer é um direito. Então, o CELLOS tem feito valer esse direito de uma forma, digamos assim, terceiro setor, vamos pensar assim, a partir da ONG. A gente sabe que tem funcionado assim e que tem tido resultados positivos, mas que nós precisamos, ainda, dessa contrapartida mínima do Estado que é com a estrutura, com recursos e precisamos mesmo disso para poder dar conta de levar essas atividades (Entrevistado 6 - CELLOS).

A partir de contextos como este que apontamos a falsa expansão das políticas públicas sociais pelo Estado, no momento em que aparentam andar juntos neoliberalismo e Estado mínimo. Contudo, o Estado nunca foi tão forte e interventor como nesse período. O que se delineou em todos os setores das políticas públicas foi uma expansão traduzida em aumento do poder do Estado como regulador das práticas ditas descentralizadoras, em vez do aumento de investimento. Segundo Amaral ${ }^{12}$, o resultado desse processo é pouco investimento estatal e muito controle sobre os negócios da iniciativa privada, e, no campo do lazer, o Estado se desresponsabiliza sobre as políticas públicas diretas, contudo estabelece leis de incentivo fiscal, investimentos diretos em empreendimentos privados. Para a autora, cresce o lazer como mercadoria de consumo e entretenimento.
Além disso, é importante ressaltar o entendimento do entrevistado do lazer como direito. Enfatizamos que foi a partir da Constituição 1988 que o lazer apareceu na lei como uma política pública. Diz a carta no Capítulo II, Dos Direitos Sociais, no art. $6^{\circ}$, que "são direitos sociais a educação, a saúde, o trabalho, a moradia, o lazer, a segurança, a previdência social, a proteção à maternidade e à infância, a assistência aos desamparados, na forma desta Constituição"13 (grifo nosso). No Título VIII, Capítulo III, da Educação, da Cultura e do Desporto, na Seção III, do Desporto, o lazer é tratado no art. $217, \S 3^{\circ}$, desta forma: "É dever do Estado fomentar práticas desportivas formais e não formais, como direito de cada um [...] $O$ poder público incentivará o lazer, como forma de promoçáo social"13 (grifo nosso).

Segundo Amaral ${ }^{12}$, foi a partir daí que governos de diferentes esferas dedicaram atenção especial à temática. A Frente Popular tem valorizado principalmente em seus discursos, o lazer como uma política pública de enorme relevância social. Contudo, considerando o modelo de Estado adotado, que congrega as duas formas de democracia, representativa e participativa, há uma acentuada valoração da participação da população no processo de concepção, operacionalização e acompanhamento das políticas públicas e, assim, o que ocorre é que as demandas por políticas públicas de lazer, em geral, quando aparecem, estão sempre em último lugar ${ }^{12}$.

Nesse processo de resposta às questóes sociais, com a refuncionalização neoliberal, os movimentos sociais de reivindicaçóes por direitos democráticos e políticos, por direitos civis, econômicos e sociais, de enfretamento ao Estado, deixaram lugar ao terceiro setor, desenvolvendo uma participação em parceria com o Estado. E, nesse sentido, as ONGs se voltam para a execução de políticas de parceria entre o poder público e a sociedade.

Ainda que permeada por essas características, as instituiçóes são um espaço de formação de novos ativistas da causa LGBT, que buscam formar consciência, despertar o senso crítico de seus integrantes, suscitar o protagonismo social e político para que, assim, possam intervir de maneira ativa na construção de sua cidadania ${ }^{14}$. No que se refere à ALEM, a instituição tem se comprometido em contribuir para o alcance da participação política do grupo buscando apoio de outros atores políticos, visando à visibilidade do segmento através de atividades diversificadas.

Além do enfrentamento público de questôes políticas, a instituição tem sido um ponto importante de sociabilidade de lésbicas em Belo Horizonte, que frequentam a entidade participando de seminários, 
oficinas, sessóes de vídeos, bate-papos e, acima de tudo, para estarem "entre iguais" e militarem por algo em que acreditam, bem como produzirem novas relações de reconhecimento identitário. E, neste contexto, a partir das atividades encontradas, aquelas nomeadas pelas dirigentes e militantes como "atividades culturais", despertaram nosso interesse.

Desde já, apontamos que não houve consenso entre as entrevistadas acerca das atividades representadas como atividades de lazer e/ou culturais, sendo esse recorte estabelecido pelo nosso olhar como pesquisadores a partir do nosso entendimento do fenômeno lazer como uma dimensão da cultura constituída a partir da vivência lúdica de manifestaçóes culturais em tempo e espaço conquistado pelo sujeito ou grupo social, constituindo relaçôes dialéticas com as necessidades, os deveres e as obrigaçôes, especialmente com o trabalho produtivo ${ }^{15}$.

Ainda assim, para as entrevistadas, há uma diferença entre as "atividades de lazer" e as "atividades culturais". Ao se nomear "atividades culturais" há um consenso no que se refere àquelas atividades voltadas para a arte e musicalidade, contudo as atividades relacionadas à atividade física, como o futebol lilás, são consideradas, pelas entrevistadas, como atividade de lazer. Segundo SiLvA ${ }^{16}$, essa relação entre o lazer e as atividades físicas pode ser compreendida considerando que, desde as origens da preocupação com o lazer no Brasil, privilegiavam-se nos programas as atividades físicas. Essa proximidade tem relação com a compreensão das atividades recreativas, principalmente como forma de recuperar a força de trabalho do operariado, apontando, assim, para o profissional de Educação Física como o perfil mais indicado e, consequentemente, as atividades físicas como as mais adequadas para atuar nos programas de $\operatorname{lazer}^{17}$.

Já no contexto do CELLOS, as açôes buscam sensibilizar os jovens, principalmente jovens da periferia. Segundo o dirigente, embora a opressão seja igual nas diferentes classes sociais, LGBTs da periferia têm menos recursos para lidar com o preconceito. Para tanto, o grupo atua em quatro frentes de ação: Educação; Cultura; Direitos Humanos; e Saúde. A partir destas frentes, encontramos atividades relacionadas ao lazer no eixo "Cultura".

É a partir desse contexto que analisamos as intervençôes no âmbito do lazer nessas organizaçóes não governamentais LGBT. Procuramos diagnosticar e analisar essas açôes, buscando identificar e analisar os objetivos, público-alvo, planejamento e avaliação, espaços e equipamentos, bem como os limites e dificuldades para o desenvolvimento dessas açôes.

\section{Conhecendo as ações de lazer}

Para o reconhecimento das açôes desenvolvidas pelas instituições no âmbito do lazer, buscamos realizar uma interlocução entre nossas observaçóes e a fala dos profissionais envolvidos. Na ALEM, as atividades são direcionadas às mulheres lésbicas e bissexuais, contudo, há uma abertura à participação de mulheres heterossexuais. É interessante ressaltar que o público alvo dessa instituição foi se transformando ao longo de sua história; inicialmente, as atividades de ALEM eram voltadas para as lésbicas, contudo outras demandas foram surgindo.

No caso do CELLOS, que trabalha com outras identidades do segmento LGBT - lésbicas, gays, travestis e transexuais -, as atividades atendem um público mais diferenciado também em relação às faixas etárias. O objetivo das açôes no âmbito do lazer é de aproximar as pessoas do movimento social, conscientizar e politizar o discurso acerca da homossexualidade. Neste contexto, um dos profissionais aponta as seguintes consideraçóes:

qual todos convergem e no qual todas as pseudo-[...] além de trazer essas pessoas para entenderem o que é o movimento, é fazer o entendimento daquelas pessoas de que a homossexualidade, a sexualidade, o gênero são coisas que a sociedade precisa discutir para avançarem na emancipação daquele sujeito que, por alguma forma sofre opressão, alguma invisibilidade, alguma violência relacionada àquela situação. É aberto para outros segmentos? É, mas especificamente nós estamos fazendo atividade para o segmento LGBT, porque entendemos que aquele segmento precisa se reunir de alguma forma, fazer alguma atividade, fazer alguma composição, mobilização que passa no mínimo uma reflexão sobre a condição daquele sujeito na sociedade em que vivemos. Então, por mais que seja através da atividade lúdica, atividade cultural, ou de outro tipo de atividade, nós precisamos falar: 'Olha, fulano de tal: você, que é homossexual, se aproxime e entenda seus direitos negados, se aproxime e entenda o mundo político da violência que você sofre, se aproxime e entenda qual é a sua condição na sociedade em que vivemos se aproxime e entenda qual interesse, quais interesses correspondidos nesse processo de opressão e violência'. Eu acho que é trazer essas pessoas pra que elas compreendam da condiçāoo delas, porque o movimento vai falar da nossa condição dos homossexuais (Entrevistado 6 - CELLOS). 
É notório que as atividades realizadas se distinguem como um meio pelo qual as instituiçôes se utilizam para trabalhar questóes relacionadas ao público LGBT, e ao movimento social, a partir de um processo educativo. Ressalto aqui a característica do duplo aspecto educativo do lazer, em que o lazer é um veículo privilegiado de educação. Para MARCELlino $^{18}$, o duplo aspecto educativo trata-se de um posicionamento baseado em duas constataçôes: a primeira, que o lazer é veículo de educação; a segunda, que para a prática das atividades de lazer se fazem necessários o aprendizado, o estímulo, a iniciação aos conteúdos culturais, que dão possibilidade à passagem de níveis menos elaborados para níveis mais elaborados, buscando superar o conformismo, pela criticidade e criatividade.

No que tange aos objetivos das atividades de lazer, outro ponto de destaque nas falas dos profissionais e dirigentes se refere à emancipação dos sujeitos envolvidos. O lazer entendido como veículo de educação se articula com o processo histórico de formaçáo de um povo, de uma sociedade, entendido este processo como desenvolvimento da qualidade política, ou seja, capacidade histórica de ocupar espaço político e cultural, de se definir e planejar, de se emancipar como sujeito histórico. Ao mesmo tempo, Demo ${ }^{19}$ ressalta que a emancipação é sempre também confronto, pois significa a conquista de espaço político próprio, diante de forças adversas restritivas. De tal modo, emancipar é verbo intrinsecamente reflexo: emancipar é emancipar-se. Portanto, no contexto do lazer, nas atividades e vivências, o profissional não pode fazer isto pelos sujeitos, mas sim, mediar este processo com os sujeitos, motivando, apoiando, instrumentalizando-o.

Assim, em relação ao lazer como veículo de educação, perspectiva que consideramos ser trabalhada nas ONGs, é importante considerar suas potencialidades para o desenvolvimento pessoal e social dos indivíduos. Igualmente, deve cumprir objetivos consumatórios, como o relaxamento e o prazer, consequentes da prática e contemplação, bem como trabalhar objetivos instrumentais, contribuindo para a compreensão da realidade. Segundo MARCELLINO ${ }^{18}$ as atividades de lazer favorecem o desenvolvimento pessoal e social, através do reconhecimento das responsabilidades sociais a partir do aguçamento da sensibilidade pessoal, ante o incentivo ao autoaperfeiçoamento, pelas oportunidades de contatos e de desenvolvimento de sentimentos da solidariedade.

Contudo, ressaltamos que, mesmo sendo fundamental que o lazer faça parte dessas oportunidades de transformação do "status quo", consideramos que não se pode depositar toda a expectativa de mudanças cristalizadas ao longo da história em uma única esfera da vida. Dessa forma, corroboramos com MARCELLINO $^{18}$ ao ressaltarmos que a perspectiva do duplo aspecto educativo do lazer marca esse campo de experiência humana, conferindo sentido à vida das pessoas pela fruição que o momento possibilita, assim como pelo processo de desenvolvimento pessoal e social de novos valores, cujo potencial pode transformar a realidade.

Ainda em relação ao público atendido, segundo os entrevistados, mesmo o CELLOS atendendo todo o segmento LGBT de uma forma geral, há um trabalhado mais direcionado ao público LGBT jovem de periferia, por entenderem que é um grupo mais vulnerável socialmente. Essa focalização da instituição pode se sustentar nas consideraçóes de NUNAN e JABLOSKI ${ }^{20}$, que apontam para a prevalência do preconceito ligado às divisóes hierárquicas de raça e classe social. Os autores consideram ser preciso atentarmos para o fato de que as divisões de raça e classe características da sociedade brasileira em geral também estão refletidas nas interaçôes entre os homossexuais.

Em relação ao lazer, detecta-se um conjunto de variáveis que têm como pano de fundo as limitaçóes econômicas, caracterizando o todo inibidor de acesso ao lazer, quer em termos de quantidade, e, principalmente, em termos de qualidade de participaçáo. Para MARCELLINO $^{18}$ a classe, o nível de instrução, a faixa etária, e o sexo, entre outros fatores, limitam a vivência do lazer a uma minoria da população. $\mathrm{O}$ autor enfatiza que tais elementos "são indicadores indesejáveis verificados no plano social da situação e necessitam, [...], ser atacados pelo movimento social embasado nos valores de democratização do lazer"18 (p.55).

Diante dessa realidade, encontramos dez atividades de lazer (cinco em cada ONG) norteadas pelo entendimento de lazer. Na ALEM, são realizados: o Futebol Lilás; a Caminhada Lésbica (ato que, perpassado pelo caráter lúdico, procura dar visibilidade à causa lésbica, sensibilizando e informando as pessoas, além de politizar as mulheres frente à questão dos direitos); Sessão Pipoca, momento em que há exibição de filmes com temáticas que abordem a cultura LGBT; as "Batucadeiras", um grupo de percussão só com mulheres lésbicas que ministravam oficinas de música e se reuniam nos parques da cidade de Belo Horizonte/MG; e "Mulheres que Pintam e Bordam", momento em que toda a comunidade é convidada a se encontrar e socializar seus saberes, através da música, da dança, do artesanato e de outras manifestaçóes culturais. $\mathrm{O}$ 
Futebol Lilás, Sessão Pipoca, as "Batucadeiras", são atividades periódicas; e a Caminhada das Lésbicas e Mulheres Bissexuais e o "Mulheres que Pintam e Bordam", eventos que ocorrem uma vez ao ano.

Já no CELLOS, as atividades realizadas são: o futebol para as lésbicas, Futebol-Lés; Vôlei da Diversidade, que de forma lúdica busca socializar integrantes do grupo e a comunidade LGBT; Vídeo Pipoca, com a mesma abordagem dada à proposta da ALEM, que propóe discutir as "temáticas LGBTs" a partir de um filme; os "Encontros Tudo a Ver", que consistem em um grupo de vivência e sociabilidade que debate vários assuntos da cultura LGBT; e a Parada do Orgulho LGBT. O Futebol-Lés, o Vôlei da Diversidade, o Vídeo Pipoca e os "Encontros Tudo a Ver", são atividades recorrentes e a Parada do Orgulho LGBT, é organizada uma vez por ano.

A Caminhada das Lésbicas e Mulheres Bissexuais e a Parada do Orgulho LGBT não são apontadas por alguns entrevistados como atividades de lazer, por afirmarem que estas são atividades de cunho político. Contudo, foi possível perceber que estas atividades têm como elemento fundante o caráter lúdico, e vêm adotando um formato de festividade, despertando o interesse das pessoas neste e, para este sentido, sem perder o viés político da ação.

Se para alguns o lazer é desvinculado desse lado político, qual seria, o objetivo dessas atividades? A partir dos relatos, percebemos que, na ALEM, não há entre as entrevistadas um consenso acerca dos objetivos dessas atividades. O que pudemos compreender foi uma relação com o resgate da autoestima do público LGBT, no qual as atividades assumem uma forma de descontração frente às mazelas da vida social, a partir desse processo de socialização. Já no CELLOS, as atividades estão relacionadas ao empoderamento desse público, visando seu protagonismo social, através do processo de socialização.

Ressaltamos que não foi possível perceber a valorização dessas açốes como um tempo, que tem um fim em si mesmo; ao contrário, as atividades de lazer são entendidas como um meio para se atingir determinado fim. Nesse sentido, ressaltamos a perspectiva do duplo aspecto educativo do lazer. Apreendemos que, no contexto das ONGs, é enfatizado o potencial educacional do lazer, ou seja, por meio dessas atividades, é possível se educar para o enfrentamento ao preconceito, seja através do empoderamento, seja trabalhando a autoestima.

Em todas as manifestaçôes culturais - físicoesportivas, artísticas, turísticas, intelectuais, manuais e sociais -, o potencial educacional do lazer está presente, sendo possíveis a reflexão e o aprendizado.
Entretanto, analisando as entrevistas, é interessante observar que mesmo que alguns dos profissionais intervêm nesta perspectiva, os mesmos parecem não se dar conta desta potencialidade em todas as atividades. Neste contexto, um dos entrevistados destaca:

Todas as nossas atividades são voltadas para formação, mesmo que seja para jogar vôlei (grifo nosso), queremos um emponderamento desse homossexual, ou seja, ele ter clareza que existe uma sociedade homofóbica, que existe uma sociedade que discrimina, que tem preconceito e que ele precisa se empoderar para lutar contra, para modificar isso (Entrevistado 4 - CELLOS).

Apontamos que em se tratando do lazer, é necessário considerar suas potencialidades para o desenvolvimento pessoal e social dos sujeitos envolvidos na ação, tanto cumprindo objetivos consumatórios, como o relaxamento e o prazer; quanto objetivos instrumentais, no sentido de contribuir para a compreensáo da realidade; e esse aspecto se dá nos seus diferentes conteúdos. Para Marcellino ${ }^{18}$, a realização de qualquer atividade de lazer envolve a satisfação de aspiraçôes de seus praticantes. Há alguma coisa em comum entre o que se busca indo ao cinema ou ao teatro, e que se difere das razóes que motivam o desenvolvimento de esportes, por exemplo. Enquanto, na primeira opção, a satisfação estética pode ser considerada como critério norteador, na segunda possibilidade, prevalece o movimento, o exercício físico.

No que se refere à cultura, foi possível perceber iniciativas de articulação entre a cultura, a educação e o lazer. Em um dos relatos, o profissional ressalta: Nós sabemos que a cultura e a educação são processos sociais que fazem com que o sujeito se socialize, se emancipe, tenha mais informação e, automaticamente, tome outros rumos que possam trazer essa emancipação. Então, o objetivo geral está dado, só que, dentro de uma entidade que vai trabalhar questôes específicas, esse objetivo vai ser trabalhado a partir de questóes específicas. Então, qual é o objetivo de fazer atividades culturais e de lazer dentro do CELLOS? Além de trazer questôes relacionadas ao lazer e à cultura para aquelas pessoas que normalmente não têm acesso a essas atividades, proporcionar esses espaços. São espaços abertos, mas ali aquele sujeito sabe que ele está indo pra aquela especificidade que é do grupo e que também é dele. Então, qual que é o objetivo de fazer? Fazer a integração e trazer a integração de sociabilidade para o grupo e para o segmento LGBT (Entrevistado 6 - CELLOS). 
Essa articulação tem em vista o processo de emancipação dos sujeitos em prol de sua autonomia, características dadas pelas ONGs às atividades de lazer. Nesse sentido, a educação para o lazer poderá contribuir, qualitativamente, para reverter os aspectos axiológicos que inibem a autonomia humana e, também, para estimular a produção de bens culturais como forma de equilibrar a relação consumo-produçáo cultural. De GÁSPARI e SCHWARTZ ${ }^{21}$ acrescentam que a significativa contribuição da educação para o lazer reside, inclusive, na perspectiva de conferir à pessoa humana sua existencialidade, a qual perpassa pela liberdade e emancipação que a distinguem como singular na diversidade cultural onde se insere e busca, incessantemente, a melhoria de sua qualidade de vida.

Apontamos para essa discussão a concepção de autonomia proposta por FREIRE ${ }^{22}$, quando afirma que educar é proporcionar autonomia de escolhas, uma cultura de vida, associando a ideia de autonomia à ideia de liberdade e de força pessoal e coletiva para intervençáo na realidade e escolha dos próprios caminhos. WIMMER e FigueIREdo ${ }^{23}$ acreditam que, pelas açôes coletivas, é possível intervir na realidade local por meio da prática da intersetorialidade, da transdisciplinaridade e da educaçáo para autonomia. A partir dessa perspectiva, a atuação no âmbito do lazer está mais próxima de pensar as necessidades da comunidade de forma mais ampla e de agir nos problemas de forma menos pontual e considerando toda sua complexidade.

Frente a esses dados, ao observarmos a proposta de emancipação a partir da interlocução entre cultura, educação e lazer traçamos uma aproximação com a proposta de Animação Cultural. Para Trilla Ber$\mathrm{NET}^{24}$, a Animação Cultural é um conjunto de ações realizadas por indivíduos, grupos ou instituiçóes, sobre uma comunidade (ou um setor desta) e no marco de um território concreto, com o propósito principal de promover uma atitude de participação ativa no processo de seu próprio desenvolvimento, tanto social quanto cultural.

A partir desta proposta pedagógica, o profissional atua como mediador, favorecendo a problematizaçáo e o questionamento da ideologia dominante, no intuito de superar a alienaçáo, no caso do lazer, desenvolvida de forma dissimulada pela indústria cultural, que, além de criar, objetiva padronizar gostos e necessidades. Dessa forma, remetemos às contribuiçóes de $\mathrm{MeLO}^{25}$, que nos diz que um dos objetivos da Animaçáo Cultural seria desorganizar pensamentos enraizados nas pessoas, desencadeando certo incômodo, possibilitando ao sujeito atentar para detalhes antes náo observados. Daí a importância desse processo ser trabalhado nos diferentes conteúdos. Contudo, a materialização desta proposta está intimamente relacionada com o planejamento dessas açóes, caso contrário ela se restringe ao campo das ideias.

Entendemos o planejamento como um processo que busca o equilíbrio entre meios e fins, entre recursos e objetivos, visando ao melhor funcionamento de empresas, instituiçôes, setores de trabalho, organizaçôes grupais e outras atividades humanas. Nesse sentido, corroboramos com PADILHA ${ }^{26}$, ao dizer que o ato de planejar é processo de reflexão, de tomada de decisão sobre a ação; processo de previsão de necessidades e racionalização de emprego de meios (materiais) e recursos (humanos) disponíveis, visando à concretização de objetivos, em prazos determinados e etapas definidas, a partir dos resultados das avaliações.

Dessa forma, o planejamento é demandado por problemas aflorados no cotidiano de trabalho e por novas questóes que surgem de forma a seguir o que está preestabelecido como objetivo para determinadas açôes. Em relação às ONGs pesquisadas, o planejamento das ações de lazer é projetado de forma distinta nas diferentes instituiçóes. No caso da ALEM, toda a comunidade atendida é convidada (via site e email) a participar do processo, intervindo diretamente tanto na elaboração e implementação, quanto na avaliação das açóes. Para tanto, a sistematização do planejamento se dá através de uma reuniáo no princípio do ano, na qual são sugeridas e escolhidas as atividades que serão realizadas ao longo do ano.

$\mathrm{Na}$ reunião de planejamento, todas as mulheres que têm uma frequência mais assídua na ALEM são convidadas a participar, conforme destaca a entrevistada 2 da instituição: "É aberto pra todas as mulheres que quiserem construir essa luta conosco". Nesse espaço são retirados os nomes das responsáveis pelas atividades, que se organizarão, para pensar o desenvolvimento daquela ação específica. Vale ressaltar que os grupos são diversificados e não necessariamente nas atividades de lazer permanecem as mesmas mulheres na organizaçáo, como também nem sempre há uma mediadora ou mediador no processo. Em cada atividade, as mulheres intervêm diretamente planejando as açóes e opinando quanto às diretrizes de desenvolvimento delas. Há uma preocupação com a construçáo coletiva das açôes, com o protagonismo e autonomia destas mulheres, no sentido de estas se constituírem como atores sociais, sujeitos da própria história. Ao mesmo tempo em que entendemos essa perspectiva, questionamos sua consolidaçáo, no sentido de pensar se era essa a proposta inicial da instituição, ou se, diante da falta 
de recursos provenientes para o âmbito do lazer, essa não passou a ser uma alternativa.

No caso do CELLOS, segue-se outro tipo de organização. $\mathrm{O}$ coletivo de direção estruturou o planejamento em duas fases: um planejamento geral, envolvendo todas as atividades da instituiçâo, e um planejamento específico, voltado para a atividade em si. Desta forma, organizam as demandas da instituiçáo em eixos de tarefas, e se subdividem em comissões que são responsáveis por cada eixo.

Diferentemente da ALEM, no CELLOS não há o envolvimento do público atendido no planejamento das atividades, cabendo ao coletivo de direção esta responsabilidade. Nesse caso, há uma preocupação com a mediação das atividades, e mesmo dividindo o grupo em comissões para o planejamento, a figura do mediador é sempre presente e anteriormente direcionada. Há uma preocupação com as demandas e interesses do público atendido, e, diante disso, para o planejamento das açóes, a comissão responsável busca articular os objetivos das atividades com estas questóes. Para tanto, utilizam os filmes, debates ou garantem em algum momento das atividades uma fala ou uma reflexão acerca destas demandas, conforme um dos profissionais ressalta:

Nós temos agora o CELLOS-Lés, um grupo de lésbicas dentro do CELLOS. Aí, pensou-se o seguinte: vamos pensar uma atividade esportiva e de lazer pra esse grupo específico. Foi feita uma consulta com esse próprio grupo e as meninas falaram: 'Ah, nós queremos o futebol', nós já temos aí uma primeira coisa, que é onde cativa. Desse próprio grupo que gostaria que fosse feito o futebol, vamos tirar o responsável, no caso. a Leandra. Ela é responsável por mobilizar as meninas pra poder fazer o futebol, que haja uma socialização e outros objetivos, sabemos que elas têm um objetivo, é de um grupo específico que vai discutir temas específicos (Entrevistado 6 - CELLOS).

Ponderamos que, de formas distintas, as duas instituiçóes percebem o planejamento em seu sentido amplo, entendendo-o como um processo. Neste sentido, compartilhamos das contribuiçôes de PADILHA ${ }^{26}$, ao apontar que este processo "visa dar respostas a um problema, estabelecendo fins e meios que apontem para sua superação, de modo a atingir objetivos antes previstos, pensando e prevendo necessariamente $o$ futuro" (p.63). Ressaltamos ainda que para tanto, é preciso considerar as condiçóes do presente, as experiências do passado, os aspectos contextuais e os pressupostos filosófico, cultural, econômico e político de quem planeja e com quem se planeja. Ressaltamos ainda a preocupação do CELLOS com a avaliação e, consequentemente, reformulaçáo das atividades, conforme aponta um dos profissionais.

De tempos em tempos, reformulamos, vemos como podemos fazer; de repente, uma atividade não está trazendo tanta gente, aí nos reunimos e analisamos o que está errado, o que podemos reformular. De repente, detectamos que está com pouca divulgação do evento, e começamos a divulgar mais o evento, chamando o pessoal para ir. Basicamente, fazemos isso, de tempos em tempos fazemos uma reformulação (Entrevistado 5 - CELLOS).

É possível destacar que ainda que não tendo uma avaliação sistematizada, os responsáveis pela atividade buscam analisar as dificuldades e os limites encontrados no sentido de rever as práticas. Compreendemos que planejar é uma atividade que está dentro da educação, por entender que é um processo que tem como características básicas: evitar a improvisação, prever o futuro, estabelecer caminhos que possam nortear mais apropriadamente a execução da ação educativa, prever o acompanhamento e a avaliação da própria ação. Portanto, planejar e avaliar quase sempre andam de mãos dadas.

Entendendo a estrutura de organizaçáo do planejamento das açôes das instituiçôes, buscamos compreender o planejamento específico das atividades de lazer, solicitando que os entrevistados levantassem elementos para essa caracterização. Novamente os sujeitos ressaltam a questão da falta de recursos financeiros:

[...] nós não temos, como uma instituição sem fins lucrativos, grana em caixa à vontade, você tem pouco recurso para poder dar sustentabilidade. Então, pensamos em coisas básicas: o local, o deslocamento, em formatar uma atividade sem custo ou com baixíssimo custo, porque não vai ter recurso disponível. Se for um projeto como o Seminário Internacional não, tem que ter muito recurso disponível, tem que ter um projeto para isso acontecer; agora, se for uma oficina ali para quinze mulheres ou se for uma atividade para cem mulheres, tem que pensar da mesma forma: não vai ter projeto, vamos ter que trabalhar com recurso nenhum (Entrevistada 3 - ALEM).

Diante da falta de recursos, outro aspecto enfatizado é a localização das atividades. Há uma preocupação em desenvolver as atividades priorizando espaços na região central da cidade, facilitando o deslocamento.

As preocupaçóes e pontos ressaltados no plano de ação das atividades de lazer de ambas as ONGs estão voltados para a estrutura física de realização 
das atividades, e pouco foi levantado em relação ao conteúdo das açôes, ao lazer em si. Entendemos que tal fato pode estar relacionado ao entendimento do que são essas atividades para as instituiçóes. Ou seja, o foco dado a elas é o da mobilização para o movimento, como abordamos anteriormente, e o lazer é um meio de educação para algo maior, a mobilização do grupo, como ressaltado pela entrevistada:

[...] deixando claro que por mais que a atividade tenha um caráter ou cultural ou de lazer como, por exemplo, o futebol tem, antes ou durante ou depois vamos ter um momento específico para poder falar da questão da mulher, para trazer informaçōes, para falar da existência da Associação, para falar do histórico da ALEM: por que a ALEM existe, por que ela está ali. Como no futebol, por exemplo, antes de começarmos, eu falo do futebol, porque foi uma ação que aconteceu dentro da Primeira Semana de Visibilidade Lésbica, antes de começar o futebol, fiz uma abertura, falei da Associação, falei do histórico da ALEM, falei o porquê que estávamos ali, falei que elas estavam ali ocupando aquele espaço machista e distribuímos informações da ALEM; entâo conversamos ali mais ou menos uns vinte minutos antes de irmos para o bom, que era jogar o futebol e depois tomar uma cervejinha, porque ninguém é de ferro (Entrevistada 3 - ALEM).

Diante disso, apontamos a importância de se considerar o lazer não só como meio para algo, mas como algo que tem sua importância em si mesmo, na fruição daquele momento, marcado por um estado de satisfação, enfatizando seu caráter desinteressado, ou seja, o lazer não está, fundamentalmente, submetido a algum fim, seja lucrativo, profissional, utilitário, ideológico, material, social, político, socioespiritual. $\mathrm{E}$, nesse sentido, pudemos observar que, na perspectiva de trabalho das atividades, o lazer não é tratado como um direito social. O interessante é que há uma demanda do público envolvido por atividades que priorizem essa fruição, e isso foi perceptível não só em nossas observaçôes, mas também nas entrevistas, como ressaltado pela entrevistada:

Existe uma demanda e muito, tanto é que no planejamento, às vezes, tira várias atividades lúdicas, porque vemos uma necessidade muito importante, porque não adianta você discutir só política, política e não ter uma atividade lúdica para que essas mulheres possam ter uma liberdade. E sentimos que, quando há uma realização dessas atividades, há uma liberdade maior, inclusive para estar falando as suas questôes (Entrevistada 2 - ALEM).
Todavia, ainda é perceptível a relação do lazer como elemento facilitador da dinâmica do grupo, como se a ele fosse dada determinada funçáo, não o caracterizando com um fim em si mesmo. Para MARCELLINO $^{27}$, o lazer na abordagem funcionalista é simples assimilador de tensóes e reparador dos efeitos negativos da força de trabalho, principalmente quando o trabalho é alienado, reforçando princípios como a manutenção da ordem e a busca pela paz social.

Para PINTO' ${ }^{28}$, muitas açóes relacionadas ao lazer no Brasil poderiam ser tachadas de "funcionalistas", tratando o lazer como recurso para acabar com a violência, com a miséria, tirar os jovens das drogas. Ressaltamos que é um equívoco reduzir o lazer a esses aspectos, bem como pensá-lo sob essa vertente, uma vez que, o lazer sozinho não é capaz de transformar a vida, nem de torná-la qualitativamente melhor (grifo nosso). Enfatizamos que, para o contexto das ONGs LGBT pesquisadas, essas ponderaçôes são importantes, nesse sentido, buscamos também identificar e compreender o processo avaliativo das atividades.

Para Freitas $^{29}$ (p. 95), os objetivos e a avaliação são categorias que se opóem em sua unidade. Os objetivos demarcam o momento final da objetivação/ apropriação, e a avaliação é um momento real, concreto, cujos resultados nos permitem confrontar o momento final idealizado, antes, pelos objetivos. A avaliação incorpora os objetivos, aponta uma direção. Os objetivos, sem alguma forma de avaliação, permaneceriam sem nenhum correlato prático que permitisse verificar o estado concreto da objetivação.

Assim, o ato de avaliar implica dois processos articulados e indissociáveis: diagnosticar e decidir. Não é possível uma decisão sem um diagnóstico, e um diagnóstico sem uma decisão é um processo abortado. $\mathrm{O}$ processo de diagnosticar se constitui da constatação e de uma qualificação do objeto da avaliação. Portanto, é preciso constatar o estado de alguma coisa (um objeto, um espaço, um projeto, uma ação, a aprendizagem, uma pessoa), tendo por base suas propriedades específicas. $\mathrm{O}$ ato de avaliar, como todo e qualquer ato de conhecer, inicia-se pela constatação, que nos dá a garantia do que o objeto é e como é. Não há possibilidade de avaliaçấo sem a constataçáa ${ }^{30}$.

E como se estrutura o processo avaliativo das ONGs estudadas? Em ambos os casos existe a avaliação das atividades, que é realizada em reunióes para esta finalidade. O que se diferencia em relaçáo às duas instituiçốes são os momentos de avaliação, que são influenciados pela forma de planejamento das açôes. Como na ALEM, as atividades são planejadas com todo o grupo, as avaliaçóes também são 
realizadas com o todo o grupo, a cada atividade. No CELLOS, é a comissão de atividades que realiza esse processo e encaminha para o coletivo de direção, o mesmo levanta os pontos em reunião. $\mathrm{O}$ registro $\mathrm{da}$ avaliação se dá através de atas, no entanto, há uma preocupação com o aprimoramento dos recursos utilizados para este processo.

Em relação aos pontos avaliados, pudemos observar certa predominância dos aspectos quantitativos e técnicos, principalmente em relação ao número de participantes e frequência destes nas diversas atividades, conforme relatado pelo entrevistado:

Sempre nós, da direção, estamos indo nas atividades, depois nas reuniões da direção vamos avaliando como é que estão as atividades. Quando começa a esvaziar muito, começamos a fazer, inventar outra forma de trazer o pessoal. O que fazemos é isso, tentamos atrair as pessoas e constantemente estamos avaliando as atividades (Entrevistado 5 - CELLOS).

Destacamos que, quando há a preocupação em avaliar a atividade qualitativamente, a questão que surge em pauta é a falta de um método, um modelo avaliativo, restringindo a avaliação às impressóes de quem organizou. $\mathrm{O}$ relato da entrevistada 1 ilustra essa preocupação, contudo não nos dá dados de como essas ideias se concretizam.

A avaliação é realizada da seguinte forma: nós fazemos um monitoramento a cada oficina: 'quem foi?', 'quem não foi?', 'por que faltou?'. Então, nós fazemos primeiro um monitoramento da frequência, fazemos um monitoramento do aprendizado também, o resultado daquela oficina: 'quem aprendeu?', quem não aprendeu?', 'quem memorizou?', 'quem tem dificuldade?', 'onde está a dificuldade?', e nessa dificuldade de perceber as dificuldades, tentamos trabalhar; se aquela pessoa teve uma dificuldade no tambor agudo, ela vai para um instrumento mais leve, vai experimentar outro instrumento, vai ter essa possibilidade, então fazemos essa avaliação. E fazemos avaliação também do processo de ensino, de como essas informaçôes são repassadas para nós, a postura da pessoa que está repassando essas informaçôes, o envolvimento dela com o grupo, o compromisso dela com o horário, o respeito com relação aos meninos que estão no processo, no grupo, então, tudo isso é avaliado, e nos reunimos e colocamos tudo no papel, cada uma vai falando o que pensa, o que percebeu, e assim fazemos a avaliação (Entrevistada 1 - ALEM).

Para ZINGONI ${ }^{31}$, um modelo avaliativo de uma atividade de lazer, significa definir com clareza os resultados esperados, a metodologia, os condicionantes e as variáveis, as relaçóes das variáveis com os resultados, os parâmetros avaliativos e de comparaçôes e os indicadores. Assim, a avaliação exercida apenas pelo julgamento das impressóes, ou do que é possível ser captado pela percepção, não pode ter "status" de avaliação. E essa é a dificuldade das ONGs, ou seja, materializar esse processo avaliativo, como ressaltado pelo entrevistado:

O que pensamos muito no sentido da avaliação, fazemos o monitoramento das atividades, é difícil de avaliar, avaliamos mesmo, é o planejamento do monitoramento que foi feito, cumpriu o objetivo? Cumpriu. Mobilizou o número de pessoas que foi legal, a reflexão aquele dia foi bacana? As pessoas participaram? Como é que foi a fala? Quem trouxe mais informaçóes? O que apareceu? Por exemplo, às vezes aparecem muitas coisas naquela reflexão, a galera não está sabendo do direito delas, por exemplo, se beijar em um bar, apareceu isso, teve um filme, e apareceu isso. Então, as avaliações são feitas muito nesse sentido, assim do que aquela atividade trouxe e naquela realização o que aconteceu, então fazemos muito nesse sentido, planejamento, monitoramento e avaliação. Planejou, alguma atividade vai acontecer todo domingo dessa forma, o monitoramento, olha como é que tem sido? A galera está participando? Na participação o que tem aparecido? Como é que tem sido feito? A organização está bacana? Como é que está sendo? Assim, vamos fazendo esse monitoramento e no final avaliamos, como é que foi? Ah, vou precisar de mais atividades para lésbicas [...] Depois disso tudo fazemos uma avaliação de como que foi a atividade, nesse sentido de melhorar mesmo e de fazer com que essa atividade continue ou também refletir, 'olha, essa atividade não está sendo uma atividade que tem sido atrativa, tem uma atividade que não tem correspondido às expectativas, vamos pensar uma outra coisa no lugar dessa atividade (Entrevistado 6 - CELLOS).

Compreendemos que, há uma ênfase na avaliação quantitativa, em que os aspectos técnicos são os pontos avaliados, havendo certa preocupação com o número de participantes e a frequência nas atividades. Esse tipo de avaliação busca descrever os significados que são observados como inerentes aos objetos e atos, por isso é definida como objetiva. Não estamos desconsiderando a importância da avaliação quantitativa, entretanto destacamos que existe o mito de que apenas o que pode ser expresso em números é permeado com a objetividade exigida para dar 
cientificidade à avaliação. No entanto, a análise e as conclusões obtidas no processo de avaliação adotandose a abordagem quantitativa não estão isentas da visão de mundo e dos valores de quem a faz. Dessa forma, a abordagem quantitativa não deve ser utilizada como algo infalível, que expressa uma verdade absoluta. Diante disso, ressaltamos a importância de uma análise qualitativa, direcionada a identificar benefícios e resultados no/para o público atendido e isso inclui a explicitação da subjetividade da percepção do outro.

Portanto, corroboramos com as contribuiçóes de Dемо $^{32}$, ao enfatizar que refletir é também avaliar, e avaliar é também planejar, estabelecer objetivos. Daí que os critérios de avaliação, que condicionam seus resultados, estejam sempre subordinados às finalidades e objetivos previamente estabelecidos para qualquer prática, seja ela educativa, social, política ou outra. Assim, seria ingênuo pensar que a avaliação é apenas um processo técnico, já que se trata também de um movimento político. Avaliar pode constituir um exercício autoritário do poder de julgar ou, ao contrário, pode constituir um processo e um projeto em que avaliador e avaliando buscam e sofrem uma mudança qualitativa. Daí a importância do estabelecimento de metodologias avaliativas, registros, e de a avaliação se dar de forma processual.

Outro aspecto que chamou nossa atenção em relação às atividades foram os espaços e equipamentos destinados à sua realização, em especial, o fato das sedes não terem espaços que contemplem todas as atividades e de a dificuldade financeira limitar outras possibilidades. Nesse sentido, procuramos não só identificar os espaços, como também descortinar os processos de aquisição dos mesmos. As sedes possuem, como equipamento material permanente e de escritório, computadores, câmeras digitais, notebooks, cadeiras/mesas - e, no caso do CELLOS, data show -, recursos adquiridos via parcerias e projetos ao longo da história das instituiçóes. Diante disso, qual o cenário destas atividades?

Nós usamos o espaço público em alguns momentos. Para as oficinas de percussão, nós utilizamos o Parque Municipal. O futebol, nós alugamos uma quadra na região central, e a gente divide, rateia esse custo com as meninas que vão jogar, as meninas que vão estar lá como torcedoras, que vão jogar, e fazemos assim. É nesses espaços, alugados ou às vezes cedidos (Entrevistada 1- ALEM).

No 'Vídeo Pipoca' a gente usa datashow, e tela pra poder colocar o vídeo. No vôlei, temos a rede, a bola, que levamos para lá, inclusive a própria escola já tem o equipamento e o 'Tudo a Ver' praticamente é uma roda de conversa que é feita aqui no espaço mesmo. Então usamos o que a entidade tem mesmo, tem de equipamento, os eventos que fazemos são todos em parceria com o poder público. Na Parada, o palco é da Belotur, grade é Belotur, não recebemos recursos, enviamos as demandas do que é necessário para fazer o evento, corremos atrás do licenciamento, da parte burocrática, tudo isso pra poder realizar, e o poder público auxilia nisso. Trabalhamos dessa forma, eu acho até melhor, porque ter recursos e depois ficar prestando conta disso é muito difícil, chato, preferimos colocar as demandas e eles encaminharem o que é necessário. Para os eventos durante a semana da Parada, geralmente mandamos um projeto pra Coordenação DST/AIDS Nacional, que tem um valor estipulado para os eventos da Parada no Brasil inteiro. Mandamos o nosso projeto, todo ano é aprovado, recebemos uma verba que dá para realizarmos. As casas noturnas de Belo Horizonte doam também e outras coisas que não tem como o poder público pagar que nós mesmos temos que pagar, então recebemos um recurso da coordenação nacional (Entrevistado 5 - CELLOS).

A questão é que, para a maioria das atividades, as sedes não dispóem de espaço físico, devido à própria estrutura das sedes, que mal comportam a parte administrativa. Cabe aqui relembrar que, na ALEM, a aquisição da sede se deu a partir do financiamento estabelecido por parcerias e, no CELLOS, ainda é por aluguel. Contudo, ambos apropriam-se das redes de mobilização para formalizar parcerias que poderão ceder espaços e disponibilizar equipamentos quando necessário. A outra possibilidade é a contribuição dos participantes no custeio das despesas com local e equipamentos.

Do mesmo modo, esbarramos na grande dificuldade da maioria das ONGs: a questão financeira. Esse aspecto, que limita muitas das açóes das instituiçóes, está intrinsecamente relacionado ao terceiro setor. É importante enfatizar que, na configuração em que as ONGs estáo dispostas, nem sempre as parcerias se dáo com facilidade, principalmente com o poder público. As duas instituiçóes passaram por situaçôes que retratam esta realidade e já indicam alguns limites e dificuldades de se trabalhar com o terceiro setor e com esse público.

Agora, por exemplo, nós estamos diante de um problema, agora nós estamos tentando arrumar um local, um galpão, ou alugar, ou arrumar 
emprestado um galpão para prosseguirmos com as atividades, com essas atividades de percussão. O Parque Municipal foi fechado para isso, então não podemos mais utilizá-lo, infelizmente, um espaço público que o público não pode participar, não pode utilizar. Que as pessoas estão reclamando do barulho. É, eu achei muito estranho, é uma maneira de fechar o espaço público para o público, porque o que vemos lá é assim. Quando fazíamos as oficinas lá, as pessoas chegavam, gostavam, elas se interagiam conosco, perguntavam como é que era aquilo, como que fazia para entrar, então percebíamos que existia um interesse. Outra coisa, não pode ser o barulho, porque os nossos instrumentos são feitos de tambor, de um tambor de plástico; o som não é um som estridente, não é um som potente, então é uma coisa mais leve, mais suave, porque não são equipamentos, não são instrumentos profissionais. Então, a alegação é essa. Eu acho que é uma maneira que eles encontraram de nos afastar do parque, até porque shows acontecem ali. Há alguns meses atrás, aconteceu um show do Paulinho Pedra Azul lá no Parque Municipal, então assim, eu não acredito que seja por causa do barulho não, essa alegação que eles tiveram não me convence (Entrevistada 1 - ALEM).

Democratizar o lazer implica em democratizar o espaço. E se a questáo for colocada em termos da vida diária da maioria da população, o espaço para o lazer é o espaço público. Quando pensamos no espaço público, nas apropriaçóes e nos diversos usos que os sujeitos atribuem ao seu espaço de vida cotidiana, é necessário conceber que essas apropriaçôes e usos fazem parte de um universo subjetivo criado por esses sujeitos em relação a esse espaço baseando-se, sobretudo, em sua vivência na cidade.

Diante da dificuldade da ALEM de utilizar o espaço do Parque Municipal Américo Renné Giannetti para a realização das oficinas de percussão e, do CELLOS, no contexto da realização da Parada do Orgulho LGBT de 2010 com a utilização da Praça da Estação, acreditamos que isso pressupóe uma territorialidade do lazer, sendo esta articulada com as relaçóes de poder, de controle e de hegemonia. $\mathrm{Ou}$ seja, cada cidadão possui um lugar socioeconômico que lhe dá mais ou menos possibilidades de acesso aos bens e serviços da rede urbana e cada cidadão tem à sua disposição diversos equipamentos e espaços de lazer criados ou revitalizados pelo poder público para o uso de todos. A territorialidade é fruto das relaçóes econômicas, políticas e culturais e, dessa forma, se apresenta em diferentes formas, imprimindo heterogeneidade ao espaço, à paisagem e à cultura, de maneira geral ${ }^{33}$.

Entretanto, quando se trata de espaços públicos e da apropriação dos sujeitos, estamos falando em direitos. A Constituição de 1988 ao tratar dos direitos fundamentais no título II aponta em seu primeiro capítulo:

Art. $5^{\circ}$. Todos são iguais perante a lei, sem distinção de qualquer natureza, garantindo-se aos brasileiros e aos estrangeiros residentes no País a inviolabilidade do direito à vida, à liberdade, à igualdade, à segurança e à propriedade, nos termos seguintes: [...] XVI - todos podem reunir-se pacificamente, sem armas, em locais abertos ao público, independentemente de autorização, desde que não frustem outra reunião anteriormente convocada para o mesmo local, sendo apenas exigido prévio aviso à autoridade competente ${ }^{13}$ (s.p.).

Nesse sentido, diante da dificuldade destacada pelas instituições em relação à utilização e apropriaçáo do espaço público, percebo que esse direito vem sendo vetado à população LGBT. Ambos os espaços citados (Parque Municipal e Praça da Estação), foram construídos para a vivência do lazer da população, sendo permitida, inclusive, a apresentação de bandas e músicos. São espaços para a sociedade civil, para os cidadãos e a cidadania enquanto inserção no espaço público necessariamente deve privilegiar a efetividade de todos os direitos ao sujeito, grupo ou comunidade.

Diante dos dados, apontamos que por se tratarem de instituiçóes que trabalham com as temáticas relacionadas à orientação sexual, frente ao preconceito e discriminação, enfrentam barreiras e dificuldades para a implementação e execução de suas atividades, fruto da homofobia que assola nossa sociedade. Para Borrillo $^{34}$, a homofobia é a atitude de hostilidade para com os homossexuais, mulheres e/ou homens, que, embora seu primeiro elemento seja a rejeição irracional ou mesmo o ódio, não pode ser reduzida a isso. Para o autor, assim como a xenofobia, o racismo ou o antissemitismo, ela é uma manifestação arbitrária que consiste em qualificar o outro como contrário, inferior ou anormal, de modo que sua diferença o coloca fora do universo comum dos homens. Para a UNESCO ${ }^{35}$, a homofobia refere-se ao tratamento preconceituoso e às discriminaçóes sofridas por homossexuais que acabam ferindo a dignidade alheia e gerando sofrimentos e revoltas.

Assim, os homossexuais são frequentemente submetidos a situaçóes de violência, constrangimento e violação de seus direitos essenciais, tal como o de ir e vir. Considerando os espaços públicos, assinalo 
que as relaçóes que perpassam a utilização e a apropriação desses espaços pelo público LGBT abrigam formas de violência específicas que em larga medida se misturam para concatenar um objetivo comum, o ódio e o repúdio aos homossexuais. A violência física e psicológica são os principais meios para se chegar a esse objetivo.

Para DAY ${ }^{36}$, a violência física ocorre quando alguém tenta ou causa dano por meio de força física, de algum tipo de arma ou instrumentos que possa causar lesóes internas, externas ou ambas. Neste quadro estáo englobadas as agressões físicas e suas expressões mais marcantes, nas quais o corpo da vítima é o "locus" de ação do perpetrador. Já a violência de natureza psicológica pode ser descrita como toda ação ou omissão que causa ou visa causar dano à autoestima, à identidade ou ao desenvolvimento da pessoa. Nos espaços públicos, a violência psicológica é constantemente operacionalizada por meio das agressóes verbais e das ameaças de agressão. Uma característica marcante deste tipo de violência é a capacidade que ela possui de difundir visôes de mundo, representaçóes e sentimentos negativos que visam gerar humilhaçáo e desprezo ${ }^{37}$.

Góis e Soliva ${ }^{38}$ ao discutirem aspectos relevantes da violência perpetrada contra jovens homossexuais em espaços públicos, apontam que além de remarcar a existência de traços extremamente violentos dos espaços públicos, os jovens homossexuais sofrem uma forte limitação dos seus direitos civis, uma vez que as experiências de constrangimento vividas nas ruas terminam por desencadear em alguns deles um recorrente medo de transitar para além dos domínios domésticos. Deparamos com complexas questóes como o exercício da cidadania, a necessidade de aperfeiçoamento das políticas públicas (em particular as de segurança) e a violação dos direitos humanos das pessoas homossexuais no que tange a igualdade entre os mesmos e os seus pares heterossexuais. Assim, apontamos que a violência contra os homossexuais, física e/ou simbólica, gera um sentimento de medo e de descrença nos aparelhos do Estado responsáveis pela manutenção da ordem e fomento dos direitos.

Górs e Soliva ${ }^{38}$ ainda apontam que o reconhecimento público da homossexualidade no 'outro' é o ponto-limite que separa os "cidadãos" dos "não cidadáos", tendo como reflexo, entre outras formas, o uso indiscriminado da violência. $\mathrm{O}$ não reconhecimento do outro enquanto sujeito de direitos, marcada por essa relação de alteridade produz efeitos objetivos que extravasam a subjetividade e trazem marcas indeléveis que concorrem para a construçáo de uma identidade homossexual positiva. Os autores afirmam que apesar dos avanços concernentes aos direitos das pessoas LGBT, sobretudo com a Constituição de 1988 e com o advento da AIDS, ainda convivemos em um ambiente de fortes tensóes, que se inscrevem em termos de possibilidades e limites de exercer esses direitos.

No que tange ao lazer, Marcellino ${ }^{27}$ enfatiza que se o espaço para o lazer é privilégio de poucos, todo o esforço para democratizá-lo não pode ficar restrito, como náo raro acontece. A ação democratizadora precisa abranger, além de pensar a construção de novos espaços, a luta pela mudança de mentalidade na utilização dos equipamentos e espaços já existentes, possibilitando a utilização e apropriação dos mesmos pela população. Desse modo, compartilho com MARCELLINO ${ }^{27}$ ao entender que a cidade constitui o espaço mais apropriado para que o lazer possa se desenvolver, local no qual a produçáo cultural pode ser devidamente estimulada e veiculada, atingindo um público significativo.

Relatar as dificuldades do trabalho com o lazer no terceiro setor visando o público LGBT não é tarefa fácil. Ao longo da análise das atividades e dos profissionais envolvidos, algumas dificuldades já puderam ser observadas, inclusive algumas que limitam a realização das atividades com qualidade. Ressaltamos que alguns apontamentos são recorrentes, sendo que muitas questóes expressam os problemas do formato no qual as ONGs estáo inseridas, de instituiçóes vinculadas ao terceiro setor.

Eu acho que exige muito uma estrutura que não temos. Se você for pensar, por exemplo, em uma atividade, vamos caminhar, vamos correr, vamos para um parque, vamos fazer uma atividade ecológica, vamos fazer um violão e voz, vamos fazer uma atividade que, por mais que vamos discutir assuntos importantes da nossa causa, do nosso processo, mas que também seja de lazer, que seja específico de lazer vai exigir uma estrutura que não temos. Vamos ter que passar por todos aqueles outros caminhos, sair da nossa estrutura física, sair da Associação (Eentrevistada 3 - ALEM).

Retomamos as consideraçóes abordadas em relaçáo ao financiamento para as ONGs, entidades do terceiro setor, e para o lazer, área fragilizada no que tange a investimentos, principalmente do setor público. $\mathrm{Na}$ visão de Mascarenhas ${ }^{39}$, o Estado deveria investir mais em políticas públicas alternativas, já que investe muito pouco na área do lazer enquanto fornece, através de empréstimos e financiamentos, o capital necessário ao poder privado, grande investidor no setor. Diante disso, propóe uma postura diferente para a atuação do Estado: em vez de patrocinar o 
desenvolvimento do lazer no contexto do mercado, o fundo estatal deveria investir "na ampliação do acesso ao microcrédito para cooperativa e política de subsídios para as pequenas empresas de lazer com atividades efetivamente orientadas para a promoção da cultura lúdica, do bem-estar humano, da dignidade das pessoas e do respeito à natureza"39 (p.194).

Por fim, ressaltamos que, apesar das dificuldades, diante dos diferentes objetivos e através de uma perspectiva diversificada, o lazer se manifesta permeando as ações realizadas por essas instituições.

Finalizando, identificamos que nos últimos anos, tem crescido no Brasil o número de estudos sobre a temática LGBT. Trata-se de um campo amplo, heterogêneo e, por vezes, contraditório, que tenta dar conta de fenômenos complexos relacionados a um segmento social que historicamente foi privado de exercer plenamente sua cidadania. No entanto, acreditamos que esse tema é ainda pouco explorado e carece de mais estudos para uma melhor compreensão sobre os significados e a dinâmica do movimento social e do público, bem como das implicaçóes e nuances políticas da entrada dessa temática na esfera pública brasileira.

Compreendemos, ainda, que o "pano de fundo" dos discursos criados frente à defesa e garantia dos direitos às pessoas LGBT é a discriminação e o preconceito, frutos da homofobia. E é esse aspecto o diferencial das organizaçóes não governamentais estudadas, que questionam as posiçóes institucionais de legitimação do silenciamento da homossexualidade para além de protestos pontuais e a histórica construção de uma cidadania LGBT "naturalmente" inferiorizada, ou subcidadania.

Desta forma, apontamos para a necessidade de um profissional, seja ele militante ou não, que atue como mediador, favorecendo a problematização e o questionamento da ideologia dominante, no intuito de superar a alienação - no caso do lazer, desenvolvida de forma dissimulada pela indústria cultural, que, além de criar, objetiva padronizar gostos e necessidades. Enfatizamos que a grande questão é a conscientização de que o lazer constitui um direito social, um momento com um fim em si mesmo. Entendemos a complexidade de desenvolver açóes e políticas que visem, de fato, à democratização do acesso ao lazer e à construção de indivíduos emancipados, sem recursos das mais variadas espécies, que englobam desde instrumentos de planejamento e avaliação até a compra de materiais e a construção de equipamentos.

Contudo, se a intenção é a consolidação do lazer como um direito de cidadania, que por sua democratização, cabe, portanto, também à categoria profissional responsável por sua promoção, incitar reflexóes sobre a configuração que tem se delineado no cenário atual das políticas públicas de lazer. Isso reforça o princípio de que nossos esforços devem se pautar pela ampliação da cidadania e pela democratização da sociedade, visando responder às complexas questóes levantadas por essas temáticas.

\section{Notas}

a. Segundo a concepçáo de Welfare State, todo o indivíduo teria o direito, desde seu nascimento, a um conjunto de bens e serviços que deveriam ser fornecidos diretamente através do Estado ou indiretamente, mediante seu poder de regulamentação sobre a sociedade civil. Esses direitos iriam desde a cobertura de saúde e educação em todos os níveis, até o auxílio ao desempregado, à garantia de uma renda mínima, recursos adicionais para sustentação dos filhos, etc. Ao longo dos anos 70 e 80, o Estado brasileiro busca organizar um "arremedo" de Welfare State, na tentativa de satisfazer algumas demandas da população desprotegida. Mesmo diante das controvérsias existentes em torno do significado dos termos utilizados para nomear o Estado Social como expóe Medeiros ${ }^{40}$ e embora essa distinção seja relevante, para fins desse estudo, os termos Welfare State, Estado de Bem-Estar Social, Estado Social Intervencionista e Estado Social são usados como sinônimos.

b. Para fins deste estudo, utilizamos o terno "militante" para nomear a participação dos sujeitos em uma organização que reivindica direitos para a população LGBT. O sujeito "militante" tem todo um envolvimento mais orgânico com o movimento social.

c. O termo "mercadorizaçâo" se insere na lógica capitalista que prioriza a acumulação de capital, sendo assim, se refere à transformação de bens, valores, conhecimento e relações em mercadoria e transação ${ }^{41}$.

d. Para fins deste estudo entendemos por serviços a operacionalização das políticas públicas. 
Tavares ML \& Isayama HF.

\begin{abstract}
On parade of leisure: outlining the leisure actions of LGBT NGOs in Belo Horizonte

The present study aimed to diagnose and analyze the actions of leisure for Non-Governmental Organizations related to the LGBT movement in Belo Horizonte/MG. Therefore, we present how the proposed methodology the documentary research combined with a field survey, applying the immersion in the field and semi-structured interviews as data collection instruments. We analyzed two institutions, through interviews with six professionals working within the recreation. The goals of these actions vary, fitting them since the work of self-esteem to the empowerment of the public seeking its social protagonism. There are a variety of actions that involve the several contents of recreation, arts, physical activities. Therefore, this work presents some challenges that invite you to think about the field of practice in recreation in LGBT NGOs, participatory planning of actions, use and appropriation of public spaces for recreation, investment in the sector, and awareness of leisure as a right.
\end{abstract}

KEY WORDS: Leisure; Professional performance; Non-governmental organization; LGBT movement.

\title{
Referências
}

1. Draibe SM. O Sistema brasileiro de proteção social: o legado desenvolvimentista e a agenda recente de reformas. Campinas: NEPP/UNICAMP; 1998. (Caderno de pesq. 1998;32).

2. Lopes TB. Sobre o fazer técnico e o fazer político: a atuação do profissional de lazer no Serviço Público Municipal [dissertação]. Belo Horizonte(MG): Universidade Federal de Minas Gerais; 2009.

3. Menicucci T. Políticas públicas de lazer: questóes analíticas e desafios políticos. In: Isayama H, Linhales, MA, organizadores. Sobre lazer e política: maneiras de ver, maneiras de fazer. Belo Horizonte: Editora da UFMG; 2006.

4. Bardin L. Análise de conteúdo. Lisboa: Edições 70; 2004.

5. Associação Lésbica de Minas. Estatuto da ALEM. Belo Horizonte: ALEM; 1999.

6. Machado FV. Muito além do arco-íris: a constituição de identidades coletivas entre a sociedade civil e o Estado [dissertação]. Belo Horizonte(MG): Universidade Federal de Minas Gerais, Faculdade de Filosofia e Ciências Humanas; 2007.

7. Fernandes FBM. "Encontros tudo a ver": reflexo dos grupos de consciência do feminismo de segunda onda na produção do sujeito político do Centro de Luta pela Livre Orientação Sexual de Minas Gerais (CELLOS/MG). Desigualdade e diversidade. Rev Cienc Soc PUC-Rio. 2009;4:33-45.

8. Centro de Luta pela Livre Orientação Sexual. Estatuto CELLOS. Belo Horizonte: CELLOS; 2003.

9. Fernandes FBM. Muito prazer, sou CELLOS, sou de luta: a produção da identidade ativista homossexual [dissertação]. Rio Grande: FURG; 2007.

10. Bresser Pereira LC. Reforma do Estado para cidadania: a reforma gerencial brasileira na perspectiva internacional. São Paulo: Editora 34; 1998.

11. Yamamoto OH. Políticas sociais, 'terceiro setor' e 'compromisso social': perspectivas e limites do trabalho do psicólogo. Psicol Soc. 2007;19:30-7.

12. Amaral SCF. Políticas públicas. In: Gomes CL. Dicionário crítico do lazer. Belo Horizonte: Autêntica; 2004. p.181-5.

13. Pinto ALT, Windt MCVS, Céspedes L, colaboradores. Brasil. Constituição da República Federativa do Brasil: promulgada em 5 de outubro de 1988. São Paulo: Saraiva; 2002.

14. Associação Lésbica de Minas. Centro de Luta pela Livre Orientação Sexual. Projeto tudo a ver. Belo Horizonte: ALEM; 2008.

15. Gomes CL. Lazer: concepçôes. In: Gomes CL, organizadora. Dicionário crítico do lazer. Belo Horizonte: Autêntica; 2004.

16. Silva AG. Trajetórias e construção do saber docente de professores universitários do campo do lazer [dissertaçáo]. Belo Horizonte(MG): Universidade Federal de Minas Gerais, Escola de Educação Física, Fisioterapia e Terapia Ocupacional; 2010.

17. Melo VA. Lazer e minorias sociais. São Paulo: IBRASA; 2003.

18. Marcellino NC. Estudo do lazer: uma introdução. 3a ed. ampl. Campinas: Autores Associados; 2006.

19. Demo P. Participação e conquista. São Paulo: Cortez; 1988.

596 • Rev Bras Educ Fís Esporte, (São Paulo) 2014 Out-Dez; 28(4):579-97 
20. Nunan A, Jabloski B. Homossexualidade e preconceito: aspectos da subcultura homossexual no Rio de Janeiro. Arq Bras Psicol. 2002;54:21-32.

21. De Gáspari JC, Schwartz GM. Adolescência, esporte e qualidade de vida. Motriz. 2001;7:107-13.

22. Freire P. Pedagogia da autonomia: saberes necessários à prática educativa. São Paulo: Paz e Terra; 1996.

23. Wimmer GF, Figueiredo GO. Ação coletiva para qualidade de vida: autonomia, transdisciplinaridade e intersetorialidade. Cienc Saúde Col. 2006;11:145-54.

24. Trilla Bernet J. Concepto, discurso y universo da animación sociocultural. Animación Sociocultural: teorias, programas y âmbitos. Barcelona: Ariel; 1997. p.13-39.

25. Melo VA. A animação cultural: conceitos e propostas. Campinas: Papirus; 2006.

26. Padilha PR. Planejamento dialógico: como construir o projeto político-pedagógico da escola. São Paulo: Cortez; 2001.

27. Marcellino NC. Lazer e educação. Campinas: Papirus; 1987.

28. Pinto GB. O lazer em hospitais: realidades e desafios [dissertação]. Belo Horizonte(MG): Universidade Federal de Minas Gerais, Escola de Educaçáo Física, Fisioterapia e Terapia Ocupacional; 2009.

29. Freitas LC. Crítica da organização do trabalho pedagógico e da didática. Campinas: Papirus; 1995.

30. Luckesi CC. O que é mesmo o ato de avaliar a aprendizagem. Rev Pátio. 2000;3. Disponível em: https://www.nescon. medicina.ufmg.br/biblioteca/imagem/2511.pdf.

31. Zingoni P. Marco lógico: uma metodologia de elaboração, gestão e avaliação de projeto social de lazer. In: Marcellino NC, Zingoni P, Pinto LMSM, organizadores. Como fazer projetos de lazer: elaboração, execução e avaliação. Campinas: Papirus; 2007.

32. Demo P. Avaliação qualitativa: polêmicas do nosso tempo. 9a ed. Campinas: Autores Associados; 2008.

33. Gil IC. Territorialidade e desenvolvimento contemporâneo. Rev Nera. 2004;7:5-19. Disponível em: http://revista.fct. unesp.br/index.php/nera/article/view/1476/1452.

34. Borrillo D. Homofobia. Barcelona: Ediciones Bellaterra; 2001.

35. UNESCO. Políticas públicas de/para/com as juventudes. Brasília: UNESCO; 2004.

36. Day VP. Violência doméstica e suas diferentes manifestaçóes. Rev Psiquiatria. 2003;25:9-21.

37. Castro M. Ressignificando sexualidade, por violências, preconceitos e discriminaçôes. In: UNESCO. Juventudes e sexualidade. Brasília: UNESCO; 2004.

38. Góis JBH, Soliva TB. A rua e o medo: algumas consideraçóes sobre a violência contra jovens homossexuais em espaços públicos. XVI Encontro Nacional de Estudos Populacionais; 29 set.-3 out. 2008; Caxambu, BR. Caxambu: ABEP; 2008. Disponível em: http://www.abep.nepo.unicamp.br/encontro2008/docsPDF/ABEP2008_966.pdf.

39. Mascarenhas F. Lazer e utopia: limites e possibilidades de ação política. In: Suassuna D, Azevedo AA. Política e lazer: interfaces e perspectivas. Brasília: Thesaurus; 2007. p.181-210.

40. Medeiros M. A trajetória do welfare state no Brasil: papel redistributivo das políticas sociais dos anos 1930 aos anos 1990. Brasília: IPEA; 2001.

41. Serra C. Mercadorização [08 jul. 2012]. Maputo: O Autor; 2012. In: Blog Diário de um sociólogo [Internet]. Disponível em: http://www.oficinadesociologia.blogspot.com.br/2012/07/mercadorizacao.html\#ixzz2jdaZKaOi.

\begin{tabular}{r|r} 
ENDEREÇO & \\
Marie Luce Tavares & \\
R. Afonso Sardinha, 90 & Recebido para publicação: 03/08/2013 \\
36420-000 - Ouro Branco - MG - BRASIL & 1a. Revisão: 20/12/2013 \\
e-mail: marieufmg@gmail.com & 2a. Revisão: 24/03/2014 \\
& Aceito: 21/04/2014 \\
&
\end{tabular}

